Sagala,D.

Peningkatan Produksi Padi...

ISSN 0854-3623

\title{
PENINGKATAN PRODUKSI PADI PADA LAHAN SAWAH TADAH HUJAN: UPAYA MENGATASI STRES TERENDAM
}

\author{
The Improvement of Rice Production on Rainfed Lowland: \\ The Attempt to Overcome Submergence Stress \\ Danner Sagala ${ }^{1}$ \\ ${ }^{1}$ Fakultas Pertanian Universitas Prof. Dr. Hazairin, SH, Bengkulu
}

\begin{abstract}
Most farmers start planting rice at the beginning of the rainy season, because the rice ecosystem consists of a rainfed lowland cultivation that fully depends on rainfall for water supply. Therefore, young rice seedlings often experience submergence stress. Carbon assimilation during submergence will be affected by several factors such as $\mathrm{CO} 2$ supply, solar irradiance, and underwater photosynthetic capacity, which is impaired by chlorosis. Poor plant growth and survival during submergence or waterlogging is often considered a consequence of the decreased diffusion of gases which affects plant growth and metabolism. Reduced $\mathrm{O} 2$ supply limits respiration, reduced $\mathrm{CO} 2$ supply limits photosynthesis and reduced ethylene diffusion away from the plant triggers chlorosis and excessive elongation of leaves of intolerant cultivars. This paper resumed the physiology of submergence tolerance and many researches that attempt to overcome submergence stress on rice. Submergence tolerance is a metabolic adaptation in response to anaerobiosis that enables cells to maintain their integrity so that the plant survives hypoxia without major damages.
\end{abstract}

Keywords: Submergence, stress, rice, production.

\section{PENDAHULUAN}

Di Indonesia, kebanyakan petani, khususnya petani sawah tadah hujan, menanam padi pada awal musim hujan, karena suplai air untuk sawah tadah hujan sangat tergantung pada air hujan. Oleh karena itu bibit padi yang masih muda sering terendam.

Banjir atau rendaman mempengaruhi 30 juta ha lahan sawah tadah hujan di Asia selatan dan Asia Tenggara (Sarkar, et al., 2003). Menurut data Depkominfo (2008), luas areal tanaman padi di Indonesia yang terkena banjir pada musim hujan tahun 2007 hingga bulan Januari 2008 ini di wilayah sentra produksi mencapai 157.651 ha, sedang yang terkena puso mencapai 59.211 ha.

Padi sawah tadah hujan terdapat sekitar 59 juta ha atau $44 \%$ dari luas total pertanaman padi Asia. Hasil rata-rata padi sawah tadah hujan masih rendah yaitu 2,1 ton/ha. Rendahnya hasil tersebut disebabkan oleh ketidakpastian ketersediaan air, rendahnya kesuburan tanah, serangan organisme pengganggu tanaman (OPT) dan lain-lain. Serangan OPT, cekaman hara, kekeringan, banjir dan interaksinya dapat terjadi secara simultan pada ekosistem sawah tadah hujan (Boling, 2007). Diantara beberapa cekaman lingkungan baik itu cekaman biotik maupun cekaman abiotik, yang mempengaruhi produksi tanaman padi, rendaman merupakan pembatas produktifitas utama ketiga karena bahkan dapat menyebabkan kehilangan hasil (Kawano, et al., 2008). Untuk meningkatkan produksi padi pada lahan sawah maka perlu pengkajian setiap faktor penghambat tersebut 
Sagala, D.

Peningkatan Produksi Padi...

dimana salah satunya adalah masalah rendaman.

Tanaman yang terendam dapat mengalami penurunan pertumbuhan, penurunan pertambahan anakan dan berat kering. Ito et al. (1999) dan Kawano et al. (2002) menyebutkan bahwa pengaruh negatif terendam terhadap tanaman terjadi akibat kerusakan mekanis pada daun, berkurangnya cahaya, terbatasnya difusi gas, keluarnya larutan dari jaringan tanaman, peningkatan kerentanan tanaman terhadap hama dan penyakit. Pada saat tanaman terendam air, suplai oksigen dan karbondioksida menjadi berkurang sehingga mengganggu proses fotosisntesis dan respirasi. Bila tanaman terendam lebih dari 4 hari, lama kelamaan akan mati (Litbang Deptan, 2007).

Menurut Jackson (2003), tanaman padi akan mengalami kerusakan yang parah apabila terendam selama beberapa hari. Rendaman akan memberi pengaruh yang serius dan bertentangan dengan kepercayaan para ahli biologi yang telah menyebar bahwa tanaman padi sangat toleran terhadap rendaman.

Oleh karena itu banyak penelitian yang telah dilakukan untuk meningkatkan toleransi tanaman padi terhadap stress lingkungan terendam. Penelitian-penelitian tersebut beragam mulai dari bidang pemuliaan, bidang ekofisiologi maupun molekuler sel tanaman terendam.

\section{FISIOLOGI TOLERANSI RENDAMAN}

Ada dua perubahan lingkungan yang terjadi saat rendaman, yaitu aerobik ke anaerobik dan sebaliknya dari anaerobik ke aerobik setelah air berkurang. Faktor kunci untuk adaptasi dari aerobik ke anaerobik adalah suplai energi. Asimilasi karbon selama terendam akan dipengaruhi oleh beberapa faktor seperti suplai $\mathrm{CO}_{2}$, radiasi matahari, kapasitas fotosintesis di bawah permukaan air yang dilemahkan oleh klorosis. Efisiensi penggunaan energi selama rendaman juga penting untuk adaptasi pada lingkungan anaerob (Kawano et al., 2008).

Menurut Sarkar et al., (2006) mengatakan bahwa toleransi rendaman merupakan adaptasi tanaman dalam merespon proses anaoerob yang memampukan sel untuk mengatur atau memelihara keutuhannya sehingga tanaman mampu bertahan hidup dalam kondisi hipoksia tanpa kerusakan yang berarti. Sebuah evaluasi terhadap padi yang toleran dan tidak toleran menunjukkan bahwa bibit padi yang toleran memiliki 30-50\% cadangan karbohidrat non struktural dibandingkan kultivar rentan. Karbohidrat ini dimanfaatkan selama terendam untuk mensuplai energi yang dibutuhkan untuk pertumbuhan dan mengatur metabolisme.

Regenerasi yang cepat setelah terendam merupakan suatu sifat yang diinginkan pada kondisi rendaman yang berulang-ulang atau lama, karena hal itu menjamin pemulitan yang cepat dan produksi biomas yang cukup untuk produktifitas yang optimum.

Daun-daun tua akan mati setelah terendam, khususnya apabila air rendaman keruh atau apabila rendaman lama. Inisisasi daun-daun baru dan pertumbuhan berikutnya membutuhkan ketersediaan karbohidrat non struktural.

Kultivar-kultivar yang mempertahankan lebih dari $6 \%$ karbohidrat non struktural awalnya pada waktu air berkurang, mampu mengembangkan daun-daun baru lebih cepat. Oleh karena itu, dapat disimpulkan bahwa status karbohidrat yang tinggi setelah terendam, yang merupakan selisih kadar sebelum terendam dengan yang digunakan selama terendam, merupakan faktor kunci yang menentukan kemampuan tanaman bertahan dalam cekaman rendaman. 
Sagala, $D$.

Peningkatan Produksi Padi...

selama

i pada

$$
\text { ). }
$$

endam, $h$ atau n-daun kutnya at non

lebih walnya nampu cepat. bahwa setelah kadar unakan kunci naman
Rendaman penuh mempercepat degradasi kandungan klorofil pada tanaman padi yang rentan dibandingkan dengan yang toleran. Sebuah perbandingan antara kandungan klorofil dan parameter fluoressen klorofil menunjukkan bahwa fluoressen klorofil lebih sensitif terhadap rendaman. Dengan mengukur fluoressen klorofil, beberapa parameter penting dapat dikuantitatifkan yang dapat membedakan dengan jelas antara kultivar yang rentan dan toleran selama $4-6$ hari rendaman, dimana kultivar rentan tidak menunjukkan tanda-tanda kematian

Tanaman padi yang membatasi pemanjangan selama terendam sering menunjukkan toleransi terhadap rendaman penuh. Beberapa peneliti menyimpulkan bahwa respons ideal terhadap rendaman adalah mampu bertahan di bawah air dan memiliki kemampuan pemanjangan. Tipe ini hanya cocok jika tinggi air meningkat dan kemudian bertahan, menurun sebagian dan akhirnya berkurang, namun meningkat lagi dan bertahan untuk waktu yang lama. Namun mengurangi pemanjangan pada kondisi terendam (1-2 minggu) vital untuk bertahan hidup sebab pemanjangan tanaman cenderung rebah setelah air berkurang. Selanjutnya, dasar pemikiran untuk mengelompokkan sebuah genotipe yang membatasi pemanjangan selama rendaman sebagai genotipe toleran adalah genotipe ini menggunakan sedikit karbohidrat yang tersedia untuk pemanjangan, sehingga cukup banyak yang dapat digunakan untuk bertahan selama rendaman dan pemulihan setelah air rendaman berkurang.

Penelitian yang melibatkan manipulasi pemanjangan pada kondisi terendam juga menunjukkan pengaruh yang menguntungkan dari penekanan pemanjangan selama terendam. Misalnya, pemberian GA pada tanaman 48 jam sebelum terendam mengakibatkan pemanjangan yang lebih aktif sehingsa menurunkan kemampuan bertahan hidup. Sebaliknya, ketika penghambat biosintesis GA, paklobutrazol diberikan, pemanjangan tunas pada kondisi terendam ditekan sehingga persentase hidup tinggi. Selanjutnya mutan kerdil yang sedikit bahkan tidak memiliki kemampuan untuk biosintesis GA menunjukkan toleransi rendaman yang sama dengan kultivar toleran FR 13A.

Pemberian penghambat biosintesis etilen, 1 metil siklopropana menurunkan pertumbuhan pemanjangan dan mampu bertahan hidup. Tanaman juga mempertahankan kadar karbohidrat yang lebih tinggi dan persentase bertahan hidup meningkat. Menurut Kawano (2002) Etilen yang terakumulasi selama terendam mempengaruhi (membahayakan) mekanisme antioksidan pada kultivar rentan, khususnya pasca rendaman. Etilen juga secara langsung mempengaruhi degradasi klorofil. Karena itu manipulasi bioteknologi yang bertujuan untuk menurunkan biosintesis $G A$ atau Etilen bisa menjadi suatu pendekatan untuk mengembangkan kultivar toleran rendaman dengan produksi tinggi.

Sintesis protein sangat dipengaruhi (membahayakan) selama terendam. Namun protein-protein anaerobik tertentu, banyak diantaranya menjadi enzim-enzim metabolisme karbohidrat, diinduksi selama terendam. Beberapa enzim yang aktif, khususnya yang berhubungan dengan metabolism energi, aktifitasnya meningkat karena efisiensi pemanfaatan cadangan karbohidrat penting untuk bertahan hidup pada cekaman rendaman.

\section{UPAYA MENGATASI STRES RENDAMAN}

\section{a. Varietas Baru}

Padi umumnya memang tahan dalam rendaman air, namun bila terlalu lama maka tanaman akan mati. Pada saat tanaman terendam air, suplai oksigen dan karbondioksida menjadi berkurang sehingga mengganggu proses fotosisntesis dan respirasi. Bila tanaman terendam lebih dari 4 hari, lama kelamaan akan mati. Sekelompok peneliti dari 
Peningkatan Produksi Padi...

IRRI dan Universitas California, Davis telah berhasil mengidentifikasi gen padi yang menyebabkan tanaman padi mampu bertahan dalam rendaman air. Penemuan ini sangat penting bagi pengembangan varietas baru padi yang tahan banjir. Dilaporkan bahwa keberhasilan penelitian tersebut berkat pemanfaatan biologi molekuler.

Melalui teknik pemetaaan gen, Tim mengidentifikasi adanya suatu klaster yang terdiri dari 3 gen yang berhubungan erat dengan proses biologi yang menyebabkan padi rentan terhadap banjir atau memungkinkan tanaman dapat bertahan dalam rendaman air. Penelitian kemudian lebih difokuskan pada salah satu dari gen tersebut yang dikenal sebagai gen Sub 1A. Keberadaan gen Sub 1A bila dalam kondisi berlebih atau hiperaktif menyebabkan tanaman padi menjadi tahan dalam rendaman air. Lebih jauh lagi ditemukan bahwa ternyata gen tersebut mempengaruhi respon tanaman terhadap hormon seperti etilen dan asam gibberelik yang berperan besar menyebabkan tanaman mampu bertahan dalam air.

Hasil penemuan ini telah diujicobakan di India. Hasilnya, tanaman padi tidak hanya toleran terhadap rendaman air namun juga memberikan hasil yang tinggi. Laos dan Bangladesh juga telah mencoba pengembangan varietas baru ini.

Dilaporkan bahwa penemuan tersebut memberikan harapan untuk meningkatkan ketersediaan pangan terutama bagi penduduk miskin di negara berkembang (Litbang Deptan, 2007).

Sarkar, et al. (2003) menguji Sembilan kultivar padi lokal dan hasil pengembangan dengan dua kultivar kontrol yang masing-masing adalah kultivar toleran rendaman (FR 13A) dengan kultivar rentan (IR 42). Hasil penelitian yang dilakukan menyimpulkan bahwa CR2003-13 and CR2006-7 dapat membantu peningkatan dan stabilitas produksi padi lahan sawah tadah hujan. Kedua kultivar ini merupakan hasil persilangan yang salah satu induknya adalah IR53508-B2-4-1-3-3 yang mewarisi sifat toleran rendaman dari FR 13A melalui BKNFR76106-160-1.

\section{b. Aplikasi $\mathrm{KHCO}_{3}$ dan $\mathrm{AgNO}_{3}$}

Krishnan (1999) melakukan penelitian untuk mengetahui pengaruh pemberian kalium bikarbonat $\left(\mathrm{KHCO}_{3}\right)$ terhadap kemampuan bertahan hidup dan pertumbuhan kultivar toleran (IR 13A) dan kultivar rentan (IR 42). Kalium bikarbonat, yang diberikan dalam dosis yang beragam dengan tujuan untuk meningkatkan konsentrasi $\mathrm{CO}_{2}$ di lahan yang terendam, meningkatkan konsentrasi oksigen lahan terendam.

Pemberian $\mathrm{KHCO}_{3}$, bahkan pada konsentrasi yang sangat rendah $0,01 \mathrm{~mol} \mathrm{~m}^{-3}$ meningkatkan kemampuan bertahan hidup kultivar rentan hingga $69 \%$, dan pada konsentrasi $0,1,0,5$, dan $1 \mathrm{~mol} \mathrm{~m} \mathrm{~m}^{-3}$ mampu bertahan hingga diatas $85 \%$. Selain itu, berat kering dan kadar klorofil kedua kultivar meningkat dengan pemberian kalium bikarbonat.

Kawano et al. (2002) melakukan penelitian mengenai pengaruh produksi etilen selama rendaman terhadap kandungan antioksidan dan kerusakan oksidatif pasca rendaman. Ketika padi digenangi selama 8 hari, kultivar toleran (BKNFR) dan kultivar rentan (Mahsuri dan IR 42) menunjukkan suatu penurunan konsentrasi askorbat. Setelah 3 hari pasca terendam, kultivar toleran menunjukkan suatu pemulihan yang cepat terhadap kadar askorbat dan asam askorbik, sedangkan kultivar rentan menunjukkan pemulihan yang lambat, pembentukan malondialdehida yang meningkat dan persentase yang bertahan hidup rendah (30\%). Namun pemberian $200 \mathrm{mg}$ $l^{-1} \mathrm{AgNO}_{3}$ yang bersifat antagonis terhadap etilen ke kultivar rentan mampu menekan penurunan askorbat dan menekan 
Sagala,D.

Peningkatan Produksi Padi...

akan hasil nya adalah ifat toleran R76106-16-

tian untuk an kalium emampuan an kultivar an (IR 42). dalam dosis an untuk lahan yang asi oksigen

konsentrasi eningkatkan var rentan $1,0,5$, dan diatas $85 \%$. orofil kedua rian kalium

penelitian len selama antioksidan rendaman. ari, kultivar in (Mahsuri penurunan hari pasca Ikkan suatu lar askorbat tivar rentan lambat, yang bertahan rian $200 \mathrm{mg}$ terhadap menekan menekan pembentukan malondialdehida yang meningkat pasca terendam serta meningkatkan persentase yang bertahan hidup hingga ratarata $60 \%$. Pemberian asam askorbik ke IR 42 yang terendam dapat menekari, pembentukan malondialdehida dengan inkubasi di bawah sinar selama 24 jam. Ada korelasi negatif antara pembentukan malondialdehida dengan konsentrasi askorbat dan persentase bertahan hidup.

Penelitian yang dilakukan menyimpulkan bahwa akumulasi etilen selama terendam memberi pengaruh yang sangat buruk terhadap mekanisme antioksidan pada kultivar rentan pasca terendam, dan asam askorbik merupakan antioksidan yang penting untuk pemulihan bibit padi.

\section{c. Pertumbuhan dan Vigor Bibit yang Baik}

Suwignyo (2005) melakukan penelitian fokus pada pemercepatan pertumbuhan pasca terendam sebagai upaya untuk pemulihan tanaman yang mengalami cekaman rendaman sehingga berproduksi tinggi. Penelitian dilakukan dengan dasar pemikiran bahwa toleransi tanaman padi terhadap kondisi terendam, dapat ditingkatkan melalui pemanfatan metode agronomis yang menghasilkan pertumbuhan tanaman yang baik dan vigor awal yang tinggi sebelum terjadinya rendaman. Melalui metode tersebut, tanaman akan mengalami kerusakan yang lebih kecil selama terjadinya rendaman.

Ehara et al. (1992) dalam Suwignyo (2005) menyebutkan bahwa dengan pemupukan nitrogen awal yang tepat akan meningkatkan vigor yang baik sehingga tanaman menjadi lebih toleran terhadap rendaman.

Penelitian yans dilakukan menyimpulkan bahwa salah satu cara untuk perbaikan budidaya tanaman di lahan rawa, disarankan untuk menggenangi bibit padi dengan larutan nitrogen 2.300 ppm selama 24 jam sebelum bibit dipindahkan. Dengan perlakuan ini akan diperoleh bibit tanaman padi yang memiliki pertumbuhan yang baik dan vigor yang tinggi sehingga apabila mengalami cekaman rendaman, tanaman ini akan mampu bertahan.

\section{PENUTUP}

Sebagian besar penduduk dunia khususnya Indonesia hidup dengan nasi (beras) sebagai makan pokoknya. Peningkatan produksi tanaman padi tentu merupakan hal yang perlu diperhatikan sebab pertumbuhan penduduk dunia setiap tahun meningkat tajam sedangkan permasalahan-permasalahan dalam produksi padi selalu bertambah. Akhir-akhir ini permasalahan global warming menjadi suatu isu yang mengancam kehidupan termasuk mempengaruhi pola produksi pertanian.

Salah satu permasalahan yang sangat penting dalam produksi padi adalah cekaman rendaman yang dapat mengganggu bahkan mengakibatkan puso. Oleh karena itu beberapa penelitian telah dilakukan, sedikit diantaranya diuraikan dalam paper ini, untuk mengatasi dan memenuhi kebutuhan akan beras.

Karena toleransi rendaman pada padi yang toleran merupakan adaptasi yang kompleks dan pengetahuan mengenai dasar fisiologi dan molekuler masih perlu penjelasan, belum ada perkembangan yang signifikan mengenai kultivar pada ekosistem ini.

\section{DAFTAR PUSTAKA}

Boling, A.A. 2007. Yield Constraint Analysis of Rainfed Lowland Rice in Southeast Asia. Ph.D Thesis. Wagenigen University. Netherland.

Depkominfo. 2008. Kebutuhan Pangan Nasional. www.indonesia.go.id didownload pada 12 Oktober 2008.

Ehara, H., M. Tsuchiya, H. Naito, and T. Ogo. 1992. Effect of the Nitrogen Treatment 
Prior to Transplanting on the Growth and Yield in Rice. Japanese Journal of Crops Science. 61(1):1-9.

Litbang Deptan. 2007. IRRI Temukan Varietas Padi Tahan Banjir. http://www.litbang.deptan.go.id didownload pada tanggal 6 Oktober 2008.

Ito, O., E. Ella, N. Kawano. 1999. Physiological Basis of Submergence Tolerance in Rain fed Lowland Rice Ecosystem. Field Crops Research. 64:75-90.

Jackson, M.B. 2003. Physiological and Molecular Basis of Susceptibility and Tolerance of Rice Plants to Complete Submergence. Annals of Botany. 91(2):227241.

Kawano, N., E. Ella, O. Ito, Y. Yamauchi, K. Tanaka. 2002. Metabolic Changes in Rice Seedlings with Different Submergence Tolerance after desubmergence. Environmental and Experimental Botany. 47: 195-203.

Kawano, N., O. Ito, J. Sakagami. 2008. Flash Flooding Resistance of Rice Oryza sativa L. and $O$. glaberrima Steud., and Interspecific hybridization progeny. Environmental and Experimental Botany. 63(1-3): 9-18

Kawano, N., O. Ito, J. Sakagami 2008. Relationship Between Shoot Elongation and Dry Matter Weight During Submergence in Oryza sativa $L$. and $O$. glaberrima Steud. Rice Cultivar. Plant Prod. Sci. 11(3): 316-323.

Krishnan, P and R. Krishnayya. 1999. Survive of Rice During Complete Submergence: Effect of Potassium Bicarbonate Application. Aust. J. Plant Physiol. 26: 793 - 800.

Sarkar, R.K., J.N. Reddy, B.C.Marndi, and S.S.C. Patnaik. 2003. New Rice Cultivars Tolerant of Complete submergence. IRRN.

Sarkar, R.K., J.N. Reddy, S.G. Sharma and A.M. Ismail. 2006. Physiological Basis of Submergence Tolerant in Rice and Implications on Crop Development. Current Science. 91: 899-906.

Suwignyo, R.A. 2005. Pemercepatan Pertumbuhan Kembali Bibit Padi Pasca Terendam : Setelah Mendapat Perlakuan "Plant Phytoregulator" dan Nitrogen. Jurnal Tanaman Tropika 8(2):4552. 